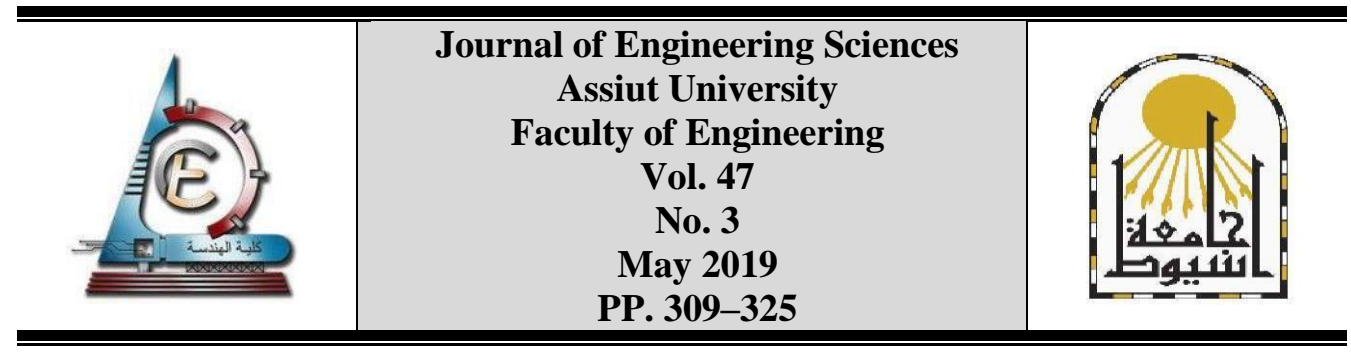

\title{
EFFECT OF URBAN FORM ON OUTDOOR THERMAL COMFORT OF GOVERNMENTAL RESIDENTIAL BUILDINGS: NEW ASWAN AS A CASE STUDY, EGYPT
}

\author{
Hatem Mahmoud \\ Dept. of Architecture, Faculty of Engineering, Aswan University, Egypt \\ Received 28 November 2018; Accepted 13 December 2018
}

\begin{abstract}
The climate change has several influences on the environment such as the Urban Heat Island phenomena (UHI) and increasing the heat waves intensity and frequency. Within a city, the outdoor spaces occupants can be impacted severely as a result of urban climate, which, in its essence, is directly linked to the buildings attributes and its configuration. the urban climate is directly linked to the configuration of buildings, building heights and their attributes. The Egyptian government's work program includes the implementation of residential units' projects for low-income citizens called "Social Housing Project". The government seeks to complete the implementation of 700,000 units within that project by the end of 2019. It has successfully undertaken more than 180.000 housing units of them by end of 2017. Most of the project exists in new cities in arid areas. While the urban planners ought to be aware of ensuring better thermal performance for outdoors urban spaces, in this project, multiple urban forms and orientations have been used. This study presents the observed and estimated relationship between the used building configurations in the case study and changes in microclimate. The study aims to extract the most effective building configuration that can improve the thermal performance of outdoors urban spaces during the summer. The data introduced in the study were based on site measurements and microclimate simulations using ENVImet. The study evaluated the impact of urban form and its orientation on air temperature and on daytime occupants' thermal comfort level. Since Sky View Factor (SVF) represents the fundamental factor controlling outdoor space diversity on the microclimate scale, it has been used to represent the urban form, and to connect between the form, sun path, and thermal behavior of the outdoor spaces. The study was conducted for the 24 hours during October assuming average climate conditions. The results showed quantitatively that there was a wide range of PET values $\left(20^{\circ} \mathrm{C}\right)$ at $12 \mathrm{PM}$, between the difference spaces owing to its shape (SVF) and orientation. These variances led to relatively comfort spaces, especially clusters which are oriented to North or North-west, and discomfort spaces with extreme heat stress, especially clusters which are oriented to South or South-west.
\end{abstract}

Findings confirmed that the main parameters affect the outdoor thermal behavior are the solar radiation and shading patterns so the urban form which gives more shade to its spaces gives more thermal comfort.

Keywords: Microclimate, Sky View Factor (SVF), ENVI-met modeling, Egypt

\section{Introduction}

Although adequate urban forms can promote favorable climatic conditions within its outdoor spaces, the weakness of environmental vision in urban design strategies often leads 
to Urban Heat Island (UHI) in many cases [1]. Johansson [2] reported that giving the thermal performance of outdoor spaces a minor role in the urban design process, is one of the most important causes of urban design deterioration. Subsequently, urban planners and decision makers should consider findings obtained from urban climatological studies in their future urban plans. Especially, Outdoor spaces within the residential compounds which are important to sustainable cities. Evaluating outdoor thermal comfort in the public areas can potentially enhance the livability of a city. Ensuring that residents are well served by outdoor spaces is essential to high-quality urban living [3]. Moreover, there is a significant correlation between urban form or urban configuration "ways of placing buildings on the land" and the potential increasing of required energy for cooling in buildings located in hot regions, like Egypt, in order to ensure comfortable conditions for their occupants. The higher energy demand resulting from the use of air conditioning affects negatively on the built environment through increasing the Urban Heat Islands UHI [1]. Accordingly, the environmental urban planning and responsive decision makers should prioritize considering thermal performance of outdoor spaces in the planning process as a strategy to guarantee thermally comfortable spaces for persons, which consequently reduces the heat stress on buildings' facades and alleviates air conditioning demand.

The Egyptian government's work program includes the implementation of residential unit projects for low-income citizens. The government seeks to complete the implementation of 700,000 units within its social housing project by the end of FY 2019 in 22 new cities all over Egypt. The government has successfully undertaken 98000 housing units of them, in 18 new cities, by the end of 2017 as the first stage [4]. The project is located in the new cities in arid areas. For that improving the urban planning process by considering the environmental aspects will have a great impact on the outdoor thermal performance of those areas. As planning the residential buildings in relation to the adjoining outdoor spaces will improve the quality of urban spaces. This strategy will foster a better urban social life, which in turn support a sustainable future of the urban communities in Egypt.

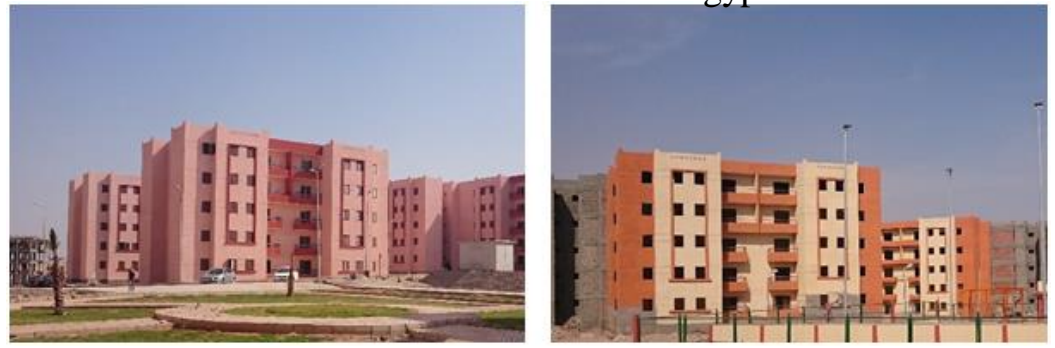

Fig. 1. The social housing project in New Aswan. Source: The author in 22-10-2016

The data introduced in the study were based on site measurements and microclimate simulations using ENVI-met, to investigate the impact of building configuration on thermal performance of outdoor spaces. The purpose of the investigation to deduce the potential relation between the thermal performance of outdoor spaces and sky view factor (SVF), which results from building configuration and its orientation. The study output can be used as a guideline to the expansion area of the social housing project in the future.

\subsection{The study problem}

The Egyptian government is seeking to implement city plans and residential projects, for new urban communities, to accommodate the large increase in the population and solve the housing problem. The social housing project is considered the most important national 
project for the low-income people in the last five years. Prioritize the outdoor thermal performance in such projects is a crucial issue, which ensure more comfort spaces for human activities, reduce the heat stress on the buildings' facades, and encourage the residents to do their outdoor activities.

\subsection{Aim}

This study seeks to contribute towards a more in-depth perception of the relation between urban form and the thermal performance of its outdoor spaces, in one of the most important governmental residential projects in Egypt. The evaluation can be used to find most suitable urban form to improve the thermal performance of outdoor spaces during the summer.

\subsection{Assumptions of the study}

The research assumes that by analyzing the thermal performance of outdoor spaces for a present case study of social housing project in hot arid new town (New Aswan city), can determine the suitable urban form and orientation that facilitate more comfortable outdoor spaces. Moreover, the resulted strategies can be considered in planning the future stages of such national projects having the same climate conditions.

\section{The research context}

Since the 1960s, the planners gave a special attention to the thermal behavior of urban blocks (groups of buildings in clusters) [5]. Changing the shape of urban block or its orientation influences its thermal behavior [6]. It is clear that the integration between buildings and urban dimensions has an immediate impact on the thermal behaviour of the investigated spaces [7]. Multiple techniques have been examined all over the world to enhance the thermal behavior of urban spaces to adapt and mitigate climate change. From those techniques the building density, orientation, roof, and ground greening cover [8] [9][10]. Martin and March examined several simplified buildings forms based on their geometry alone. The initial studies focused on courtyards and pavilions forms [11]. The performance of each technique may vary based on the climate and the built environment in which they are implemented [12]. However, in hot arid climate, achieving shelters from solar radiation is the main challenge to design comfort outdoor spaces. Shading is considered the main parameter that influences the thermal conditions in the warm and hot climates [13]. For that, to identify the best mitigation solutions adapted to a particular building environment, the thermal performance should be tested by running micro-climate models, and then the efficiency of each solution is tested. Then the results can be utilized based on the similar built environment and regional climate, and based on a given set of climate-related parameters such as aspect ratio, albedo or vegetation density [12].

\subsection{Thermal comfort}

To evaluate and compare the thermal behavior of urban spaces, it is important to note that there are six parameters influencing the sensation of thermal comfort within a space. Some of these factors are related to environmental conditions and others are related to personal conditions. Environmental conditions include four parameters; a) air temperature, b) mean radiant temperature, c) relative humidity, and d) airstream velocity. Whereas the personal conditions include two parameters: a) clothes, and b) human activity level [14]. For that comparing between different spaces within the same neighborhood based only on air temperature parameter is insufficient, since it will vary temporarily through the day, but 
the spatial differences among the various spaces in the same time is very close (Less than 1 $\left.{ }^{\circ} \mathrm{C}\right)$ [15]. Accordingly, the comparison process to evaluate the urban spaces in the case study will be conducted based on the six factors influencing the thermal comfort. The thermal comfort indices adopted in this study is Physiological Equivalent Temperature (PET) expressed in $\left({ }^{\circ} \mathrm{C}\right)$. It is an up-to-date thermal index. It is based on "human energy balance and considers the thermo-regulatory capacity of the human body to adjust to stressful microclimates" [16]. PET is an effective tool for the evaluation of the thermal component of different climates [17]. It has 6 grades starting with extreme cold stress for physiological temperature less than $4^{\circ} \mathrm{C}$, and ranging to Extreme heat stress with physiological temperature over $41^{\circ} \mathrm{C}$ as shown in Table 1 .

\section{Table 1.}

Physiological Equivalent Temperature grades on human beings in typical case [17]

\begin{tabular}{cll}
\hline $\begin{array}{c}\text { PET } \\
\left({ }^{\circ} \mathrm{C}\right)\end{array}$ & \multicolumn{1}{c}{$\begin{array}{c}\text { Thermal } \\
\text { perception }\end{array}$} & \multicolumn{1}{c}{$\begin{array}{c}\text { Grade of } \\
\text { physiological stress }\end{array}$} \\
\hline 4 & Very cold & Extreme cold stress \\
8 & Cold & Strong cold stress \\
13 & Cool & Moderate cold stress \\
18 & Slightly cool & Slight cold stress \\
23 & Comfortable & No thermal stress \\
29 & Slightly warm & Slight heat stress \\
35 & Warm & Moderate heat stress \\
41 & Hot & Strong heat stress \\
& Very hot & Extreme heat stress \\
\hline
\end{tabular}

\subsection{Sky View Factor SVF}

SVF is "a climatological parameter used to characterize radiation properties on urban areas and to express the relationship between the visible area of the sky and the portion of the sky covered by buildings viewed from a specific point of observation" [18]. Its value ranges from 0 to 1 (zero mean no sky visible). SVF value directly influences the long-wave radiation term in the urban space. When SVF increases, it reduces the long-wave radiation flux emitted by built surfaces to the sky during night-time [12]. Also, in the space, there is a linear relationship between the net solar radiation and the value of SVF [19]. SVF is one of the main causes of the urban heat island phenomena. Therefore, it is required as a parameter in our case study in New Aswan city. SVF can be obtained using digital camera with Fisheye lens in the site.

SVF value can be estimated using several methods; on-site methods (fisheyes-lens), and mathematical methods (photographs analysis, and image processing). Since we haven't a fisheye lens, we could use a borrowed camera for one day, and got SVF image for point 3. Then, the study has used an application named "Sky Helios" to generate all the sky view images [20]. This tool replaces the use of a 180 fisheye-lens camera. We had compared between the SVF values generated from fisheyes-lens photographs with Sky Helios output to validate its generated images (Fig. 2). From the sky view images, the SVF was calculated using Rayman "a public domain software" developed by Andreas Matzarakis [21]. 

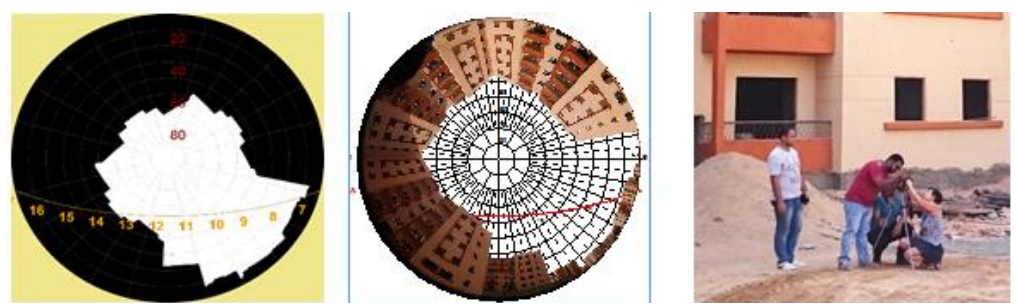

Fig. 2. Comparison between SVF obtained from Rayman and SVF obtained from SkyHelios. Source: Author 3. Area of study

New Aswan city is a new city in South of Egypt $\left(24^{\circ} 11^{\prime} \mathrm{N}, 32^{\circ} 40^{\prime} \mathrm{E}\right.$, and $157 \mathrm{~m}$ altitude). It was established in 1999 on an area of 3900 acres, which was extended to 18490.92 in 2015. It is located on the west bank of the River Nile, $12 \mathrm{~km}$ north of Aswan city (Authority, 2017).

Aswan has a hot-arid climate. The annual average temperature is $25.9{ }^{\circ} \mathrm{C}$; the average maximum temperature in the summer is $42{ }^{\circ} \mathrm{C}$, and the mean temperature in the summer is $37{ }^{\circ} \mathrm{C}$ temperature is and the average annual precipitation is $1 \mathrm{~mm}$, with a high presence of clear-sky conditions [22].

The study focuses on a cluster of a social housing project in New Aswan city. It is a national housing project in all of Egypt. It has a typical apartment and building model. The government has a plan to establish other phases for the social housing project, for that improving its urban geometry based on environmental vision can imply a wide influence on the thermal performance of its spaces and the energy efficiency. The cluster is composed of 76 residential buildings, including 1520 apartments; the total area of the cluster is $95000 \mathrm{~m} 2$. It had been built to accommodate about 7600 inhabitants.

\section{Methodology}

This study presents the observed and estimated relationship between the used building configuration in the case study and changes in microclimate. The simulation was conducted with the aid of ENVI-met version 4. The simulation results were compared with the site measured to validate the simulated model. SVF has been generated to determine its value and the sun path diagram to determine the hours that the space is subjected to the direct solar radiation. The thermal comfort indicis PET has been calculated and compared for all outdoor spaces surrounded with the residential buildings (21 space), to address the influence of urban form (SVF, orientation, ...etc) on thermal performance of urban space. Finally, the relationship between the direct solar radiation, thermal comfort, and urban form was examined.

\section{Monitoring}

The study area has a multiple urban form and orientations. We could characterize 21 form as shown in (Fig. 3) with multiple properties as shown in Table 2. Since we have only 4 data loggers to record the temperature and the relative humidity $(\mathrm{RH})$. We have built a simulation model in ENVI-met software ver.4, to can evaluate the thermal performance of 21 buildings configuration in the study area.

The measurement was taken in $22^{\text {nd }}$ Oct. 2017 to validate the simulation. The reason for choosing such a time period is primarily because this period is representing the typical summer days in Aswan, and due to the convenience of having the field team assembled for those occasions. 
Measurements were carried out at three points, spanning up to $24 \mathrm{~h}$ (typically from 8 am to $7 \mathrm{am}$ local time). Three HOBO Onset data loggers (at approximately $1.5 \mathrm{~m}$ height) for air temperature and humidity were used. Data were registered at the loggers and recorded every 30 minutes.

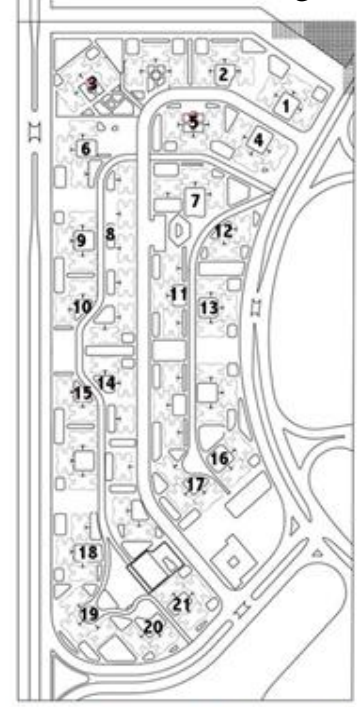

Fig. 3. the characterized 21 forms in the study area Source: Author

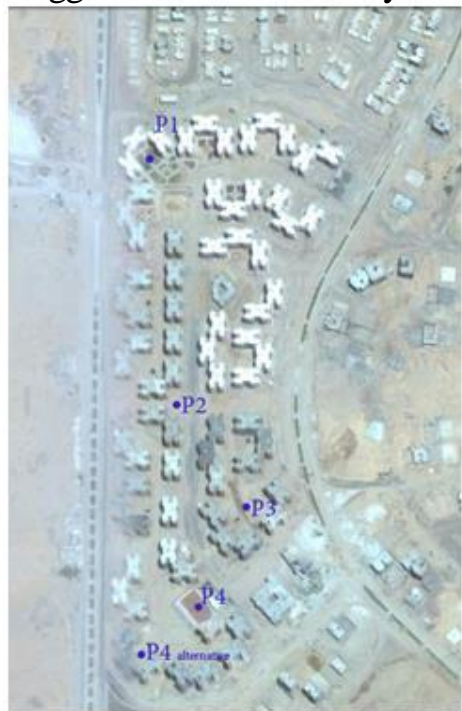

Fig. 4. The selected point Source:[25] edited by the Author.

Table 2.

The properties of selected 21 points (SVF, Orientation, and shape)

\begin{tabular}{|c|c|c|c|c|c|c|c|}
\hline Point & SVF & Orientation & Shape & Point & SVF & Orientation & Shape \\
\hline 1 & 0.359 & Southwest & & 12 & 0.666 & North \& West & \\
\hline 2 & 0.364 & South & & 13 & 0.347 & West & \\
\hline 3 & 0.351 & Southeast & & 14 & 0.437 & South \& West & \\
\hline 4 & 0.366 & Southwest & & 15 & 0.432 & North \& East & \\
\hline 5 & 0.366 & North & & 16 & 0.407 & $\begin{array}{c}\text { Southwest\& } \\
\text { Northwest }\end{array}$ & \\
\hline 6 & 0.403 & East & & 17 & 0.426 & Northeast & \\
\hline 7 & 0.431 & South & & 18 & 0.425 & East & \\
\hline 8 & 0.687 & West & & 19 & 0.406 & Northeast & \\
\hline 9 & 0.340 & East & & 20 & 0.464 & $\begin{array}{c}\text { Northeast \& } \\
\text { Northwest }\end{array}$ & \\
\hline 10 & 0.455 & South \& East & & 21 & 0.311 & Southwest & \\
\hline 11 & 0.367 & East & & & & & \\
\hline
\end{tabular}




\subsection{Simulation process}

In this study, ENVI-met was used. It is "a holistic three-dimensional simulation of surface-plant-air interactions embodying the proposed scenarios" [23]. It is designed for microscale with a resolution from 0.5 to 5 meters and a typical time frame of 24 to 48 hours [23]. This software has been used and tested in many studies to simulate urban built environments, and has been validated for its ability to simulate thermal environmental conditions on the microclimate scale [24].

The study area was modeled in ENVI-met. The modeling included the pavements. To determine the suitable sitting, different model domains and resolutions were tested. The model was run with $(125 * 250 * 24)$ grid units at $3 * 3 * 3 \mathrm{~m}$ resolution. Moreover, to increase the simulation stability with objects close to the border of the model, three nesting grids on each side were added. A receptor (weather data) was placed at the middle of each investigated form (total 21 receptors) to record the simulation output at these points through the simulation process (Fig. 4).

We ran ENVI-met for a 28 hours period, starting at 04:00 AM, with constant time steps (2 s) and model output every $60 \mathrm{~min}$, using the configuration parameters listed in Table 3 . The first 4 hours of the model run was discarded, as a spin-up time is required for ENVI-met to get better results. The material assigned for all buildings was considered the same for ease of use.

Table 3.

The boundary conditions used in running the simulated model in ENVI-met

\begin{tabular}{llll} 
Start date & 22.10 .2016 & $\begin{array}{l}\text { Wind direction } \\
(\mathrm{N}=0, \mathrm{E}=90)\end{array}$ & $275.5 \mathrm{Degree}$ \\
\hline Period & $28 \mathrm{~h}$ & $\begin{array}{l}\mathrm{RH} \\
\text { (in } 2 \mathrm{~m})\end{array}$ & $50 \%$ \\
\hline Spatial resolution & $\begin{array}{l}2 \mathrm{~m} \text { horizontal. } 2 \mathrm{~m} \\
\text { Vertical. }\end{array}$ & Specific Humidity at $2500 \mathrm{~m}$ & $4.16 \mathrm{~g} / \mathrm{kg}$ \\
\hline Initial air temp. at $4 \mathrm{AM}$ & 24.27 & Albedo (walls) & 0.5 \\
\hline $\begin{array}{l}\text { Wind velocity at } 10 \mathrm{~m} \\
\text { height }\end{array}$ & $0.5 \mathrm{~m} / \mathrm{s}$ & &
\end{tabular}

\subsection{Validating of ENVI-met}

The simulation model was validated by comparing the site measurements and simulated data outputs. In the site survey. Four data loggers $\left(\mathrm{P} 1^{\text {ref }}, \mathrm{P} 2^{\text {ref }}, \mathrm{P} 3^{\text {ref }}\right.$, and $\left.\mathrm{p} 4^{\text {ref }}\right)$ as shown in (Fig.4), however, we got results from the first three points only and lost the fourth device. The weather data for the simulation were taken from a weather station located about 3 kilometers from the site in Aswan University campus in New Aswan city. The first simulation with normal type (initial boundary conditions only) gave low validation results. For that, the simulation was repeated with forced type (24 input for temperature and relative humidity) to have more accurate results.

To validate the model, Willmott (1981) suggested the following methodology using Root Mean Square Error (RMSE) and the coefficient of determination $\left(\mathrm{R}^{2}\right)$. The average difference between measured and simulated values was calculated with RMSE representing the general model performance [26]. $\mathrm{R}^{2}$ represents the proportion of the variance in the dependent variable (simulated data) that is predictable from the independent variable (measured data), for a model to be considered reliable, R2 should tend to $\rightarrow 1$ [27]. 
The measured and simulated air temperature records at (P1ref, P2ref, and P3ref) were compared as shown in (Fig. 5). The simulation model overestimate peak temperature with about $2 \mathrm{C}$. however the overall differences between the measured and simulated data is usually normal when the validation parameters (RMSE, R2) exist within the normal range. The simulation results underestimate at daytime, and overestimate at night.

RMSE of the air temperature between simulation and measurement was 1.72 on $\mathrm{P}^{\text {ref }}{ }^{\text {, }}$, 1.63 on $\mathrm{P} 2{ }^{\text {ref }}$, and 2.26 on $\mathrm{P} 3{ }^{\text {ref }}$. These values are considered improvement than those in other studies [28] [26], where the model was still accepted even though RMSE reached 3.42 [26]. For data sampling points, $\mathrm{R}^{2}$ was 0.86 on $\mathrm{P} 1^{\text {ref }}, 0.91$ on $\mathrm{P} 2{ }^{\text {ref }}$, and 0.80 on P3 ${ }^{\text {ref }}$ (Fig. 5), indicating that the simulation model captured the measured air temperature trends well. The inadequate computation of materials heat capacity in ENVI-met, as reported in literature, can lead to these differences [29] [26].

The study purpose is to compare the relative thermal performance for multiple urban forms within a residential site. Hence, we consider the validation parameters adequate for the microscale simulation. The agreement between simulation and measurement coped with most literature.

\section{Sky View Factor (SVF)}

The analysis of thermal performance presented in this study is concerned with the impact of urban geometry, using as an indicator the Sky View Factor (SVF) of several points, on local outdoor spaces and on comfort levels in the study area. Those monitoring points were defined for the selected 21 form, from P1 to P21, in the study area (Fig. 3), comprising of all blocks' forms. As mentioned, all SVF images were extracted using SkyHelios software as shown in (Fig. 6). It is noticeable that most spaces exposed to direct solar radiation are spaces with south, southeast, and southwest orientations (P1, P2, P3, P7, $\mathrm{P} 8$, and P21). The maximum number of exposed hours to solar radiation was experienced in P7 with 7 hours from 9 AM to $4 \mathrm{PM}$. As the urban spaces that were oriented to the north, northeast, and northwest were less exposed to the solar radiation (P4, P5, P15, P16, P17, $\mathrm{P} 19$, and P20). The rest of the spaces varied in terms of orientation and exposure to the sun. 


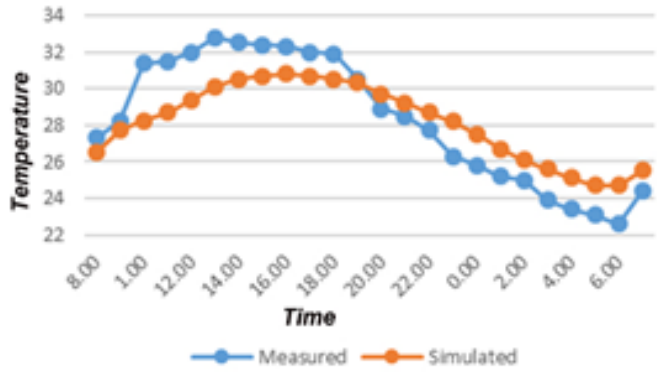

a) $P 1^{\text {ref }}$

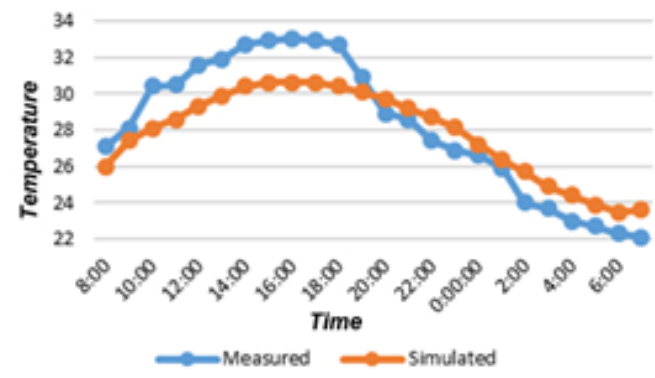

c) $\mathrm{P} 2^{\text {ref }}$

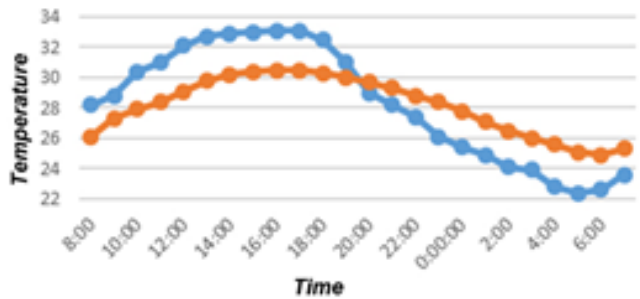

- Measured $\longrightarrow$ Simulated

e) P3ref

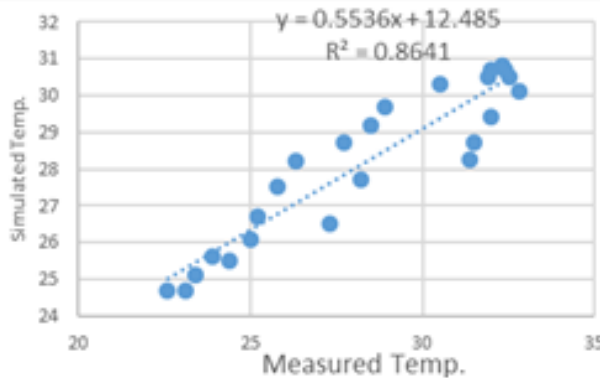

B) Trendline of (P1 $\left.1^{\text {ref }}\right)$ and its $R^{2}$

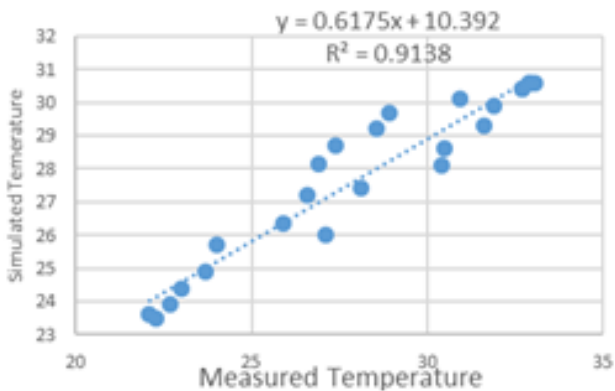

d) Trendline of ( $\left.\mathrm{P} 2^{\text {ref }}\right)$ and its $\mathrm{R}^{2}$

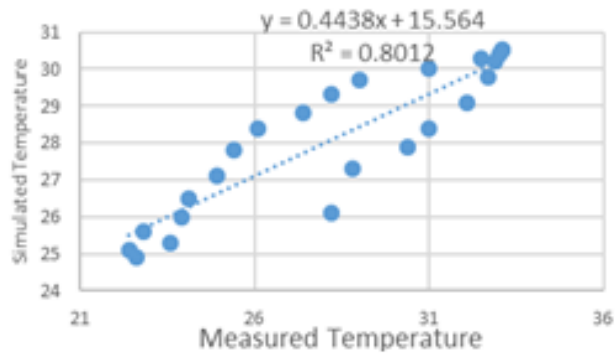

f) Trendline of (P3 $\left.3^{\text {ref }}\right)$ and its $R^{2}$

Fig. 5. Validation results for diurnal hourly air temperatures at a) $\left.\mathrm{P} 1^{\text {ref }}, \mathrm{c}\right) \mathrm{P} 2^{\text {ref }}$, and e) $\mathrm{P} 3^{\text {ref }}$. Correlations between measured and simulated air temperatures at b) $\mathrm{P}^{\text {ref }}$, d) $\mathrm{P} 2^{\text {ref }}$, and e) $\mathrm{P} 3^{\text {ref }}$. 

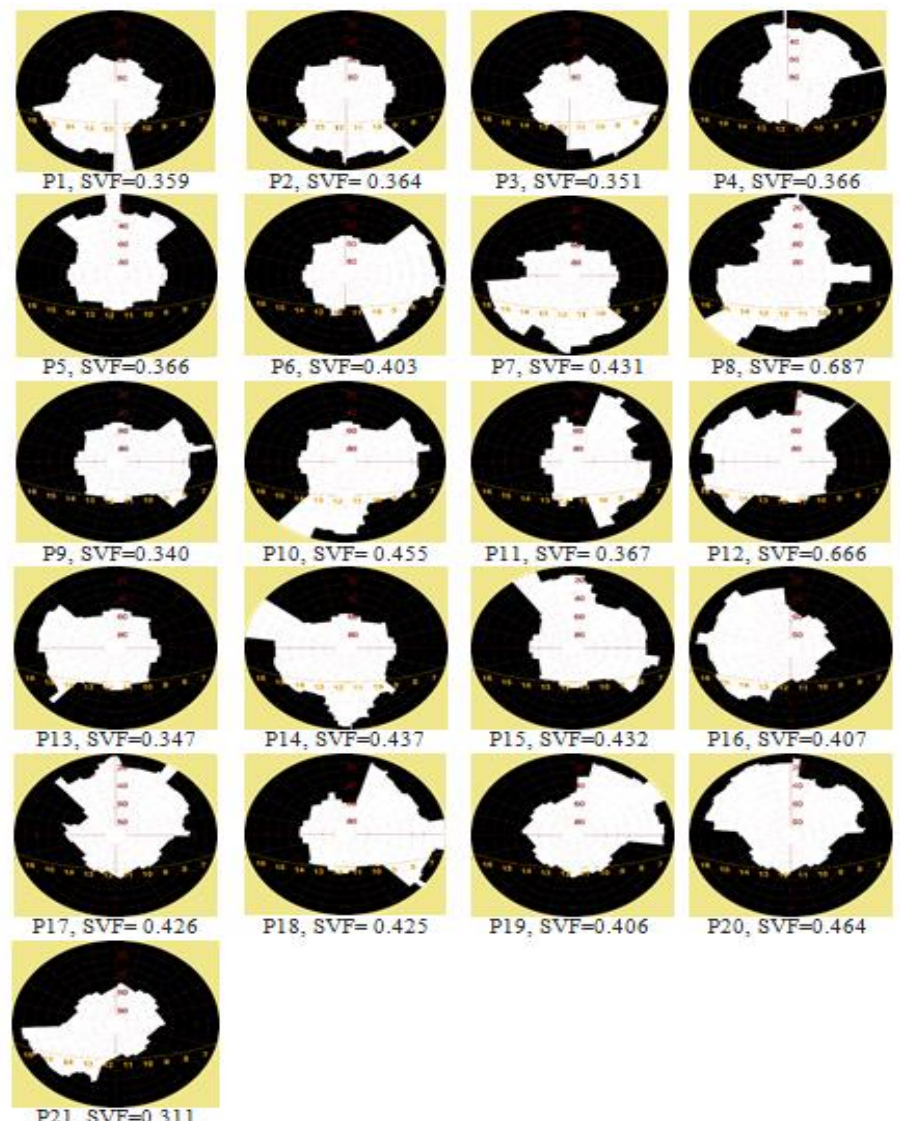

Fig. 6. Generated Fisheye images from SkyHelios and its SVF for the monitoring point - Source: Author

\section{Results and discussion}

The simulation procedures were carried out by preparing the model for the simulation and calculating the outdoor air temperature and Physiological Equivalent Temperature (PET) as well.

Table 4 shows the simulation output for the air temperature in the 21 monitoring points from $8 \mathrm{AM}$ to $5 \mathrm{PM}$ which represent the 21 urban form that are included in the case study, where the figure 8 shows the same results for 24 hours ( 8 AM to 7 AM). The results indicated that the peak air temperature through the day was $33.6{ }^{\circ} \mathrm{C}$ in $\mathrm{P} 10$ at $12 \mathrm{PM}$ and continued as higher point till 1 PM with point P14 and P21. However, the difference through these 2 hours (1 AM and $2 \mathrm{PM}$ ) between maximum and minimum temperature was only $0.5^{\circ} \mathrm{C}$. the lowest temperature through the peak hours was in $\mathrm{P} 4, \mathrm{P} 5, \mathrm{P} 11$, and P17. It is noted that differences in air temperature values between the different spaces is very small. The differences between higher and lowest temperature at each hour ranged from 0.2 to $1.7^{\circ} \mathrm{C}(20$ hours $\leq 1{ }^{\circ} \mathrm{C}$ ). The small differences in our case owing to simplifying the buildings and keeping the same building's materials in order to understand the relative impact of urban form and its orientations. Since SVF is close in the most spaces (from 0.35 to 0.45 ). It is observed that the highest temperature found in the south and southwest oriented spaces, and the lowest was in north and northwest spaces owing to its lower exposure to direct solar irradiation, and the wind direction (The prevailing winds are northwesterly). 
Hatem Mahmoud, Effect of urban form on outdoor thermal comfort of governmental

Although temperature differences among investigated spaces are not great, we cannot ignore them, as the literature [30] [31] has shown that a $1^{\circ} \mathrm{C}$ reduction in outdoor space temperature, could realize a $5 \%$ savings in the energy consumption of buildings.

Table 4.

The hourly air temperature for the 21 monitoring points $\left({ }^{\circ} \mathrm{C}\right)$ (Bold is peak and lowest values)

\begin{tabular}{|c|c|c|c|c|c|c|c|c|c|c|}
\hline Time & $8: 00$ & $9: 00$ & $10: 00$ & $11: 00$ & $12: 00$ & $1: 00$ & $2: 00$ & $3: 00$ & $4: 00$ & $5: 00$ \\
& AM & AM & AM & AM & PM & PM & PM & PM & PM & PM \\
\hline P1 & 29.4 & 30.8 & 32.2 & 32.9 & 33.4 & 33.2 & 32.6 & 31.9 & 31.1 & 30.4 \\
\hline P2 & 29.6 & 30.9 & 32.2 & 32.9 & 33.3 & 33.1 & 32.6 & 32.0 & 31.1 & 30.4 \\
\hline P3 & 29.6 & 30.9 & 32.1 & 32.9 & 33.3 & 33.1 & 32.6 & 32.0 & 31.0 & 30.3 \\
\hline P4 & 29.4 & 30.7 & 32.0 & 32.6 & 33.1 & 32.8 & 32.4 & 31.8 & 31.0 & 30.3 \\
\hline P5 & 29.4 & 30.7 & 31.9 & 32.7 & 33.1 & 32.9 & 32.4 & 31.9 & 31.0 & 30.3 \\
\hline P6 & 29.9 & 30.9 & 32.1 & 33.0 & 33.4 & 33.0 & 32.6 & 31.9 & 31.0 & 30.2 \\
\hline P7 & 29.4 & 30.8 & 32.1 & 32.9 & 33.3 & 33.1 & 32.6 & 31.9 & 31.0 & 30.4 \\
\hline P8 & 29.5 & 30.8 & 32.3 & 33.0 & 33.5 & 33.2 & 32.6 & 31.9 & 31.0 & 30.3 \\
\hline P9 & 29.7 & 30.9 & 32.1 & 33.0 & 33.4 & 33.1 & 32.5 & 31.9 & 31.0 & 30.2 \\
\hline P10 & 29.7 & 31.0 & 32.2 & 33.1 & 33.6 & 33.3 & 32.8 & 32.1 & 31.0 & 30.3 \\
\hline P11 & 29.7 & 30.9 & 31.9 & 32.7 & 33.1 & 32.8 & 32.3 & 31.8 & 31.0 & 30.3 \\
\hline P12 & 29.3 & 30.6 & 31.7 & 32.6 & 33.2 & 33.0 & 32.5 & 31.9 & 31.0 & 30.4 \\
\hline P13 & 29.4 & 30.7 & 32.2 & 32.8 & 33.3 & 33.0 & 32.4 & 31.8 & 31.0 & 30.3 \\
\hline P14 & 29.4 & 30.8 & 32.3 & 33.1 & 33.5 & 33.3 & 32.8 & 32.0 & 31.0 & 30.2 \\
\hline P15 & 29.5 & 30.8 & 32.1 & 33.0 & 33.4 & 33.2 & 32.6 & 32.0 & 31.0 & 30.2 \\
\hline P16 & 29.4 & 30.6 & 31.8 & 32.7 & 33.4 & 33.2 & 32.7 & 31.8 & 31.0 & 30.4 \\
\hline P17 & 29.4 & 30.6 & 31.9 & 32.6 & 33.1 & 32.9 & 32.4 & 31.8 & 31.0 & 30.3 \\
\hline P18 & 30.1 & 30.9 & 32.0 & 32.9 & 33.3 & 33.0 & 32.5 & 31.9 & 30.9 & 30.2 \\
\hline P19 & 29.5 & 30.9 & 32.1 & 32.8 & 33.3 & 33.0 & 32.5 & 31.9 & 31.0 & 30.2 \\
\hline P20 & 29.4 & 30.7 & 31.7 & 32.6 & 33.2 & 33.0 & 32.5 & 31.9 & 31.0 & 30.3 \\
\hline P21 & 29.3 & 30.6 & 31.9 & 32.7 & 33.4 & 33.3 & 32.8 & 32.0 & 31.0 & 30.3 \\
\hline
\end{tabular}

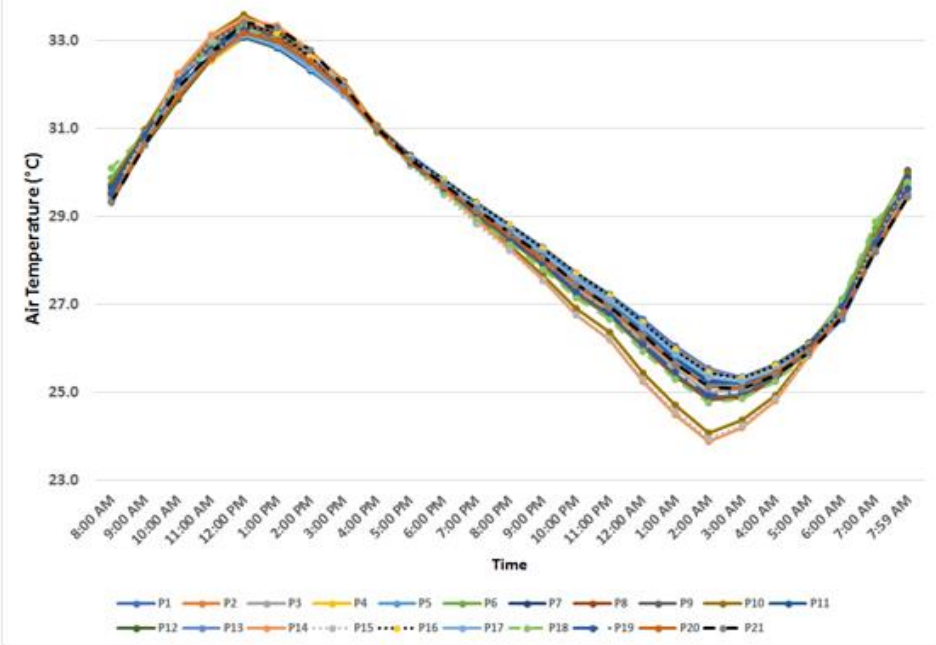

Fig. 8. Diurnal profile of the hourly air temperature for all monitoring points (21 point) 
The study aims to evaluate the impact of urban form on the thermal comfort of outdoor spaces. The air temperature values can not be considered as a final indicator for the thermal comfort, since the air temperature is considered one of six parameters influencing the thermal comfort as stated earlier. The real and clear indicator is PET.

It is noted the distribution of PET values based on the simulation results as shown in Fig.9. although all the buildings and its urban spaces have the same height and material, the site experienced a range of PET values from 31.97 to $50.4^{\circ} \mathrm{C}$ (about $18.5^{\circ} \mathrm{C}$ ) at $3 \mathrm{PM}$. Since the PET values after the sunset tend to be very close, we focused on PET values in daytime where the values differences are significant as shown in Table 5 and Figure 10. The red border of cells in Table 5 indicates a surge in values up at each space. The most uncomfortable period was $10 \mathrm{AM}$ to $12 \mathrm{PM}$. PET peak values, occurred in the afternoon mostly at 12PM and ranged in 11 points (P1 to P3, P7 to P10, P13, P14, P16, and P21) from 54.7 to $62.8{ }^{\circ} \mathrm{C}$. On the contrary, at the same hour (12PM) the points (P4 to P6, P11, P12, $\mathrm{P} 15$, and P17 to P20) the PET value ranged from 41.8 to $42.9^{\circ} \mathrm{C}$. the differences in PET at the daytime reached about $20^{\circ} \mathrm{C}$ between the spaces in the same hour due to the various period of space exposure to the direct radiation as a result of urban form and orientation.

Regarding the orientation, the best values of the PET occurred in the clusters which are oriented to North or North-west, while the worst values occurred in the clusters which oriented to South, South-West or to the West. This is owing to the correlation between urban form and sun path diagram as shown in Fig.6, and the wind direction which mostly comes from northwest in New Aswan City.

Comparing the SVF images in Fig. 6, PET values in Table 5, PET profile at P2, P4, and P7 (Figs 11, 12 and 13) gives a clear indicator for the correlation between urban form (SVF value and orientation) and PET values. When the urban form has a shape and orientation that allows a longer time of protection from direct solar radiation, PET profile (curve) behavior continues smooth through the day, such as P4 (Fig. 11). On the contrary, when the urban form and its orientation allows long time for the direct solar radiation, a sudden up shift occurred for PET value in the space for a period nearly close to the exposure period. The direct exposure lead to more heat stress on the space occupants and on the buildings' facades.

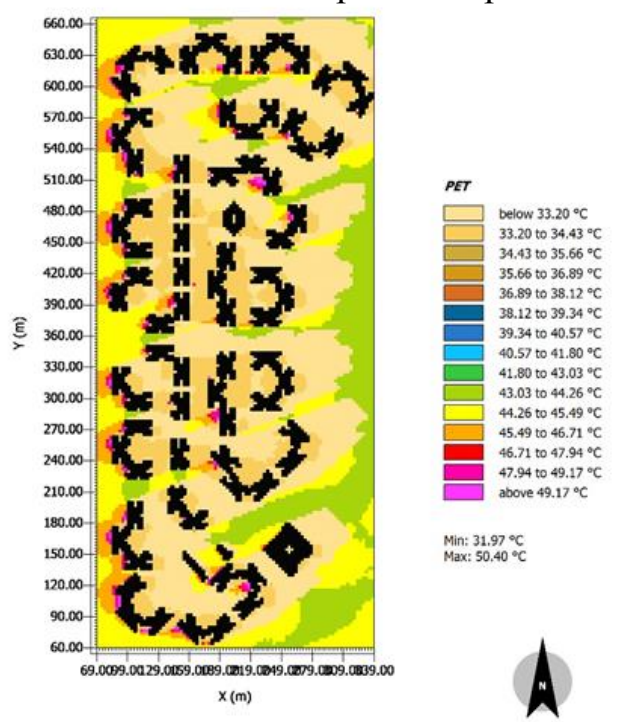

Fig. 9. Map of PET values for the case study area at 3 PM 
Hatem Mahmoud, Effect of urban form on outdoor thermal comfort of governmental

Table 5.

The hourly PET values for the 21 monitoring points $\left({ }^{\circ} \mathrm{C}\right)$, the Red bold border indicates to surge in value up

\begin{tabular}{|c|c|c|c|c|c|c|c|c|c|c|}
\hline Time & $\begin{array}{l}8: 00 \\
\mathrm{AM}\end{array}$ & $\begin{array}{l}9: 00 \\
\text { AM }\end{array}$ & $\begin{array}{c}10: 00 \\
\text { AM }\end{array}$ & $\begin{array}{c}11: 00 \\
\text { AM }\end{array}$ & $\begin{array}{c}12: 00 \\
\text { PM }\end{array}$ & 1:00 PM & 2:00 PM & 3:00 PM & 4:00 PM & 5:00 PM \\
\hline Pl & 33.6 & 37.8 & 57.0 & 58.2 & 59.4 & 59.2 & 56.2 & 33.4 & 28.3 & 27.1 \\
\hline P2 & 34.0 & 57.2 & 59.4 & 61.0 & 62.8 & 41.6 & 38.4 & 33.7 & 28.4 & 27.2 \\
\hline $\mathrm{P3}$ & 52.4 & 55.2 & 57.0 & 58.2 & 59.6 & 40.7 & 37.7 & 33.3 & 28.2 & 27.0 \\
\hline P4 & 33.7 & 37.9 & 40.9 & 42.2 & 42.4 & 40.8 & 37.9 & 33.4 & 28.2 & 27.1 \\
\hline P5 & 33.8 & 38.0 & 41.2 & 42.6 & 42.9 & 41.2 & 38.2 & 33.6 & 28.4 & 27.2 \\
\hline P6 & 50.6 & 53.2 & 55.0 & 56.5 & 42.3 & 40.6 & 37.6 & 33.2 & 28.1 & 26.9 \\
\hline P7 & 33.4 & 54.2 & 56.4 & 57.6 & 59.0 & 58.8 & 56.2 & 48.6 & 28.2 & 27.1 \\
\hline P8 & 32.9 & 37.0 & 53.1 & 54.5 & 55.8 & 55.6 & 53.3 & 33.0 & 28.0 & 26.8 \\
\hline P9 & 51.2 & 54.2 & 56.0 & 57.4 & 58.8 & 40.8 & 37.8 & 33.4 & 28.2 & 27.0 \\
\hline $\mathrm{P} 10$ & 49.8 & 52.2 & 53.9 & 55.1 & 56.2 & 40.4 & 37.4 & 33.1 & 28.0 & 26.8 \\
\hline P11 & 53.6 & 56.4 & 58.0 & 42.0 & 42.4 & 40.8 & 37.9 & 33.4 & 28.2 & 27.1 \\
\hline $\mathrm{P} 12$ & 32.8 & 37.0 & 52.7 & 54.0 & 41.8 & 40.1 & 52.5 & 45.6 & 27.9 & 26.8 \\
\hline $\mathrm{Pl3}$ & 33.3 & 37.4 & 56.0 & 57.2 & 58.6 & 40.7 & 55.6 & 33.3 & 28.2 & 27.1 \\
\hline $\mathrm{Pl4}$ & 32.8 & 50.6 & 52.4 & 53.6 & 54.7 & 54.4 & 52.1 & 32.9 & 27.9 & 26.7 \\
\hline P15 & 33.1 & 37.3 & 54.1 & 55.4 & 42.1 & 40.4 & 37.5 & 33.1 & 28.0 & 26.8 \\
\hline $\mathrm{P} 16$ & 33.1 & 37.3 & 40.4 & 55.8 & 57.1 & 56.8 & 54.2 & 33.1 & 28.0 & 26.9 \\
\hline $\mathrm{P} 17$ & 33.7 & 38.0 & 41.2 & 42.6 & 42.8 & 41.0 & 38.0 & 33.4 & 28.3 & 27.1 \\
\hline P18 & 33.5 & 37.4 & 56.2 & 41.9 & 42.2 & 40.6 & 37.7 & 33.3 & 28.1 & 26.9 \\
\hline P19 & 33.4 & 54.0 & 55.8 & 42.1 & 42.3 & 40.6 & 37.6 & 33.2 & 28.1 & 26.9 \\
\hline $\mathrm{P} 20$ & 33.2 & 37.4 & 40.5 & 42.1 & 42.3 & 40.6 & 37.6 & 33.2 & 28.1 & 26.9 \\
\hline $\mathrm{P} 21$ & 32.9 & 37.1 & 40.3 & 55.4 & 57.0 & 56.8 & 54.3 & 46.2 & 28.1 & 26.9 \\
\hline
\end{tabular}

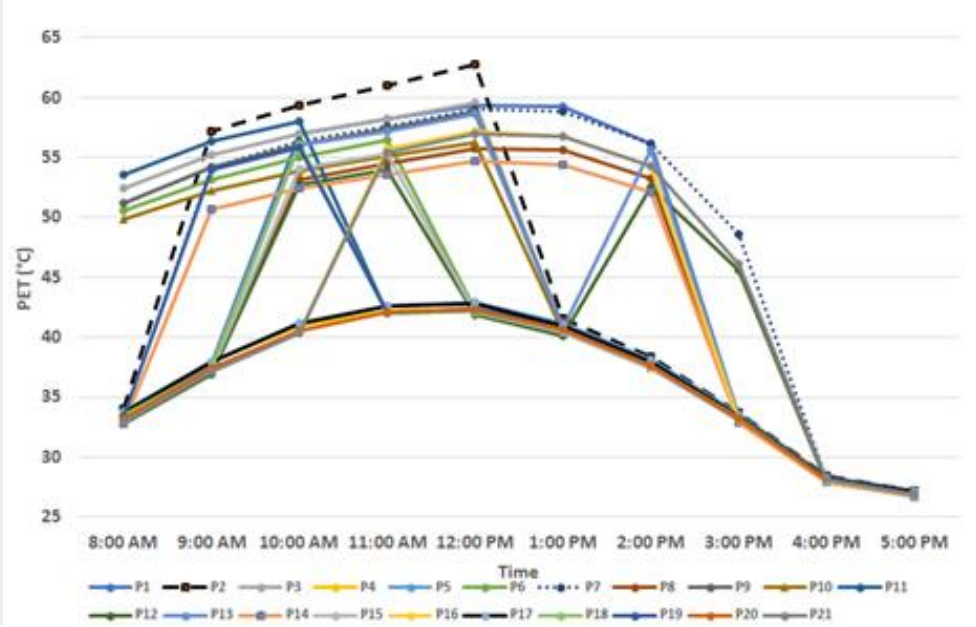

Fig. 10. Daytime profile of the hourly PET for all monitoring points (21 point) 


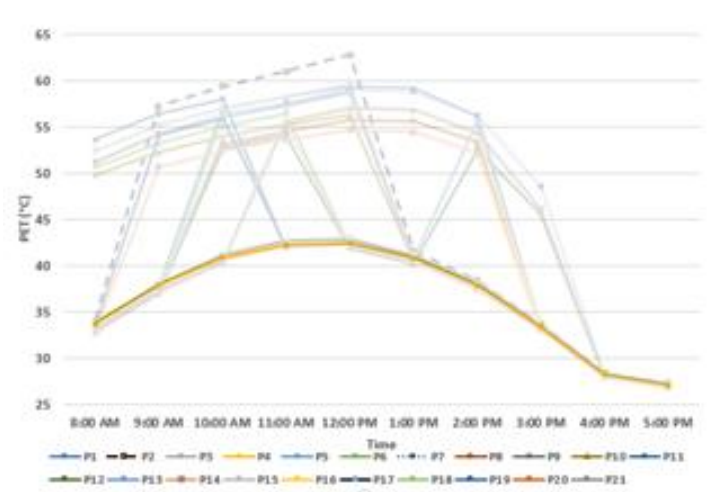

a) Daytime profile of the hourly PET for P4

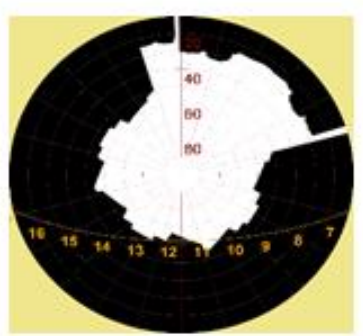

b) P4, SVF 0.366

Fig. 11. the smooth PET curve in $\mathrm{P} 4$ as a result for its urban form and orientation

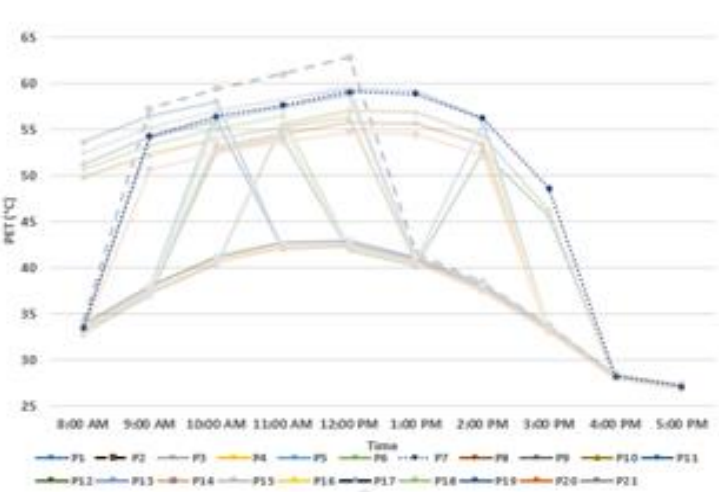

a) Daytime profile of the hourly PET for P7

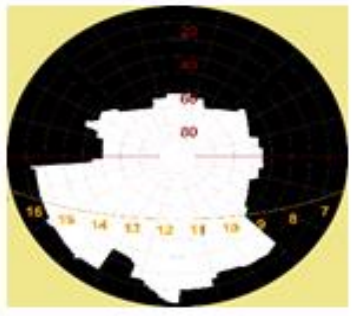

b) P7, SVF 0.431

Fig. 12. the sudden up shift for PET curve in $P 4$ as a result for its urban form and orientation (7 hours exposed to direct solar radiation)

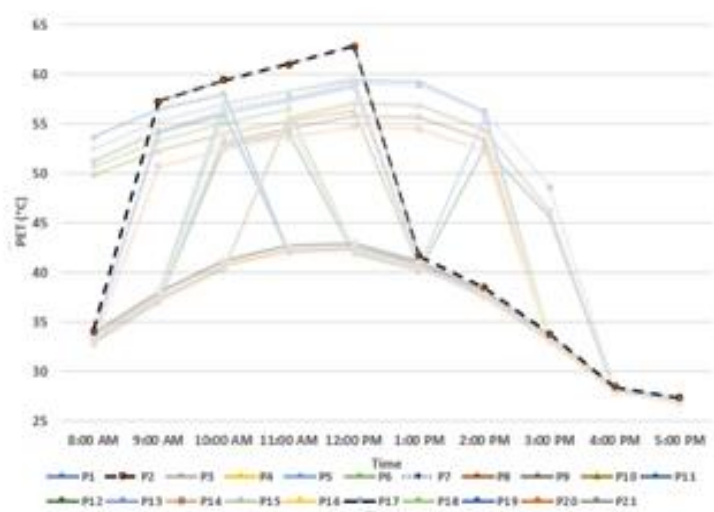

a) Daytime profile of the hourly PET for P2

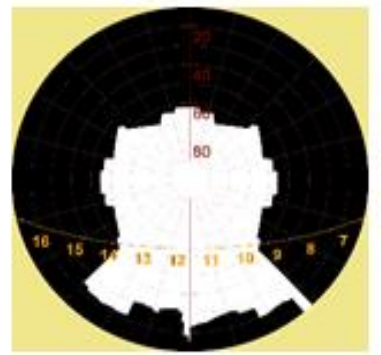

b) P2, SVF 0.364

Fig. 13. the sudden up shift for PET curve in $\mathrm{P} 4$ as a result for its urban form and orientation (4 hours exposed to direct solar radiation)

\section{Conclusion}

The aim of the study was to evaluate the thermal performance of outdoor spaces in the social housing project, in New Aswan city as a case study. The evaluation was conducted 
by quantifying the impact of the urban form (buildings blocks) on the outdoor spaces thermally. The findings would help to identify the suitable model for the urban geometry concerning the environmental vision in an important national residential project.

In this study, we determined 21 model for the urban form in the case study.

The results showed quantitatively that there was a wide range of PET values $\left(20{ }^{\circ} \mathrm{C}\right)$ between the difference spaces owing to its shape (SVF) and orientation. These variances led to relatively comfort spaces and discomfort spaces with extreme heat stress.

The appropriate urban form with its SVF and orientation should be considered as an effective factor in conducting the thermal comfort of the outdoor spaces. The intensity of direct vertical solar radiation is the most influential factor on PET value.

It can be said that the sustainable design can improve the thermal comfort of the outdoor residential spaces, where the thermal comfort efficiency is a trade-off between different design factors to achieve a target level of comfort, which varies according to the climatic design of outdoor spaces.

\section{Recommendations and Future vision}

It is essential to work on the integration between the building and the external surrounding spaces; the results prove the vitality of using the compact pattern as an adaptation strategy on the scale of urban development in Egypt. This vitality is not only for the newly constructed developments but also for the already existing ones and gives an impression about how can invest in our built environment.

There are many mitigation factors affecting the thermal performance of the outdoor spaces such as the vegetation, materials albedo, and building compactness. It is important to evaluate the impact of each factor and the its suitable configuration. Many studies are required to realize a comprehensive sustainable urban planning for the new cities in Egypt. Accordingly, the case introduced in this study will be developed in the future to include other mitigation factors.

\section{REFERENCES}

[1] E. L. Krüger, F. O. Minella, and F. Rasia, "Impact of urban geometry on outdoor thermal comfort and air quality from field measurements in Curitiba, Brazil," Build. Environ., vol. 46, no. 3, pp. 621-634, 2011.

[2] E. Johanssson, Urban Design and Outdoor Thermal Comfort in Warm Climates, Stud ies in Fez and Colombo. 2006.

[3] L. Chen and E. Ng, "Outdoor thermal comfort and outdoor activities: A review of research in the past decade," Cities, vol. 29, no. 2, pp. 118-125, 2012.

[4] NUCA, "New Urban Communities Authority NUCA," 2018. [Online]. Available: http://www.newcities.gov.eg/Default.aspx.

[5] H. Sanaieian, M. Tenpierik, K. Van Den Linden, F. Mehdizadeh Seraj, and S. M. Mofidi Shemrani, "Review of the impact of urban block form on thermal performance, solar access and ventilation," Renew. Sustain. Energy Rev., vol. 38, pp. 551-560, 2014.

[6] V. Gupta, "THERMAL EFFICIENCY OF BUILDING CLUSTERS: AN INDEX FOR NON AIRCONDITIONED BUILDINGS IN HOT CLIMATES,” Energy Urban Built Form, pp. 133-145, Jan. 1987.

[7] H. Andrade and M. J. Alcoforado, "Microclimatic variation of thermal comfort in a district of Lisbon (Telheiras) at night," Theor. Appl. Climatol., vol. 92, no. 3-4, pp. 225-237, 2008.

[8] M. Taleghani, L. Kleerekoper, M. Tenpierik, and A. van den Dobbelsteen, "Outdoor thermal comfort within five different urban forms in the Netherlands," Build. Environ., vol. 83, pp. 65-78, Jan. 2015.

[9] F. Yang, S. S. Y. Lau, and F. Qian, "Thermal comfort effects of urban design strategies in high-rise 
urban environments in a sub-tropical climate," Archit. Sci. Rev., vol. 54, no. 4, pp. 285-304, 2011.

[10] M. Srivanit and K. Hokao, "Evaluating the cooling effects of greening for improving the outdoor thermal environment at an institutional campus in the summer," Build. Environ., vol. 66, pp. 158-172, 2013.

[11] C. Ratti, D. Raydan, and K. Steemers, "Building form and environmental performance: Archetypes, analysis and an arid climate," Energy Build., vol. 35, no. 1, pp. 49-59, 2003.

[12] J. Bernard, E. Bocher, G. Petit, and S. Palominos, "Sky View Factor Calculation in Urban Context: Computational Performance and Accuracy Analysis of Two Open and Free GIS Tools," Climate, vol. 6, no. 3, p. 60, 2018.

[13] R. Emmanuel, H. rosenlund, and E. Johansson, "Urban shading - a design option for the tropics? A study in Colombo, Sri Lanka," Int. J. Climatol., vol. 27, no. September, pp. 1995-2004, 2007.

[14] T. Honjo, Thermal Comfort in Outdoor Environment, vol. 13. 2009.

[15] T. Sharmin and K. Steemers, "Effect of Canyon Geometry on Outdoor Thermal Comfort : A case-study of high-density , warm-humid climate," Plea 2013, no. September, 2013.

[16] P. Höppe, "The physiological equivalent temperature - a universal index for the biometeorological assessment of the thermal environment," Int. J. Biometeorol., vol. 43, no. 2, pp. 71-75, Oct. 1999.

[17] A. Matzarakis, H. Mayer, and M. G. Iziomon, "Applications of a universal thermal index: Physiological equivalent temperature," Int. J. Biometeorol., vol. 43, no. 2, pp. 76-84, 1999.

[18] L. Cristina and L. De Souza, "A 3d-gis extensionf for sky view factors assessment in urban environment," no. June, 2014.

[19] A. Bernabé et al., "Radiative and heat storage properties of the urban fabric derived from analysis of surface forms," Urban Clim., vol. 12, pp. 205-218, 2015.

[20] A. Matzarakis and O. Matuschek, "Sky view factor as a parameter in applied climatology - Rapid estimation by the SkyHelios model," Meteorol. Zeitschrift, vol. 20, no. 1, pp. 39-45, 2011.

[21] A. Matzarakis, F. Rutz, and H. Mayer, "Modelling radiation fluxes in simple and complex environmentsapplication of the RayMan model," Int. J. Biometeorol., vol. 51, no. 4, pp. 323-334, Feb. 2007.

[22] "World Weather Online." [Online]. Available: https://www.worldweatheronline.com/aswanweather-history/aswan/eg.aspx. [Accessed: 15-Jun-2018].

[23] Michael Bruce, "ENVI-met," 2018. [Online]. Available: https://www.envimet.com/introduction/.

[24] M. Taleghani, D. Sailor, and G. A. Ban-Weiss, "Micrometeorological simulations to predict the impacts of heat mitigation strategies on pedestrian thermal comfort in a Los Angeles neighborhood," Environ. Res. Lett., vol. 11, no. 2, 2016.

[25] Google, "Web Google Earth." [Online]. Available: https://earth.google.com/web/. [Accessed: 20-Oct-2017].

[26] A. Middel, K. Häb, A. J. Brazel, C. A. Martin, and S. Guhathakurta, "Impact of urban form and design on mid-afternoon microclimate in Phoenix Local Climate Zones," Landsc. Urban Plan., vol. 122, pp. 16-28, 2014.

[27] V. P. López-Cabeza, C. Galán-Marín, C. Rivera-Gómez, and J. Roa-Fernández, “Courtyard microclimate ENVI-met outputs deviation from the experimental data," Build. Environ., vol. 144, no. July, pp. 129-141, 2018.

[28] W. T. L. Chow and A. J. Brazel, "Assessing xeriscaping as a sustainable heat island mitigation approach for a desert city," Build. Environ., vol. 47, no. 1, pp. 170-181, 2012.

[29] R. Emmanuel and H. J. S. Fernando, "Urban heat islands in humid and arid climates: Role of urban form and thermal properties in Colombo, Sri Lanka and Phoenix, USA," Clim. Res., vol. 34, no. 3, pp. 241-251, 2007.

[30] Y. Chen and N. H. Wong, "Thermal benefits of city parks," Energy Build., vol. 38, no. 2, pp. 105-120, 2006.

[31] N. H. Wong, A. Y. K. Tan, P. Y. Tan, and N. C. Wong, "Energy simulation of vertical greenery systems," Energy Build., vol. 41, no. 12, pp. 1401-1408, 2009. 


\section{تأثير الثكل الحضري على الراحة الحرارية الخارجية في مباني الإسكان النكومي مدينة أسوان الجديدة كمثنال}

\section{الملخص العربى}

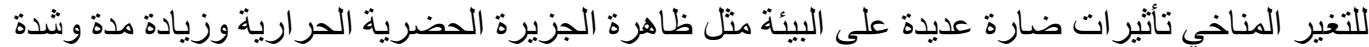

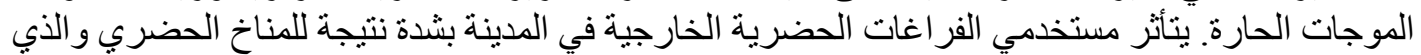

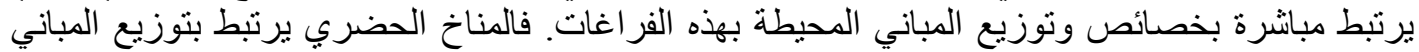

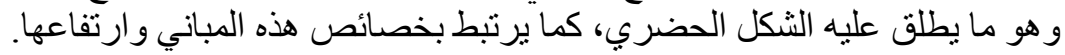

تعمل الحكومة المصرية على برنامج قومي يشمل توفير وحدات سكنية لمحدودي الاخل بسمى (مشري

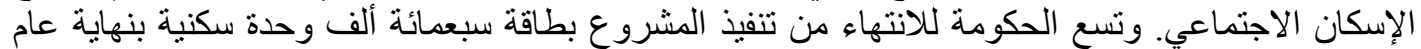

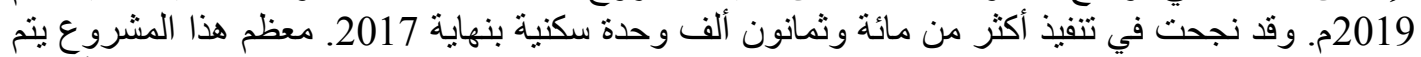

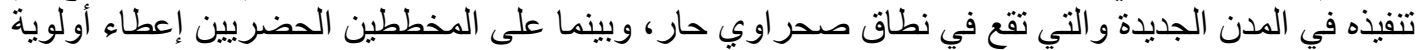

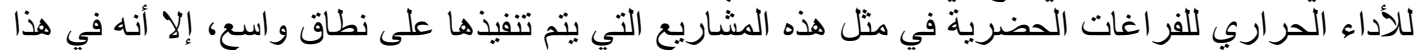

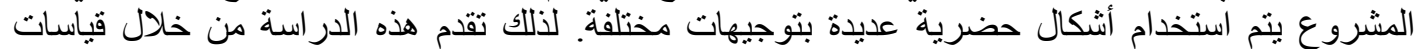

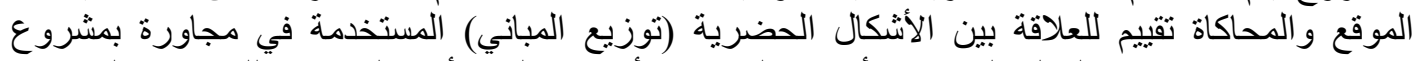

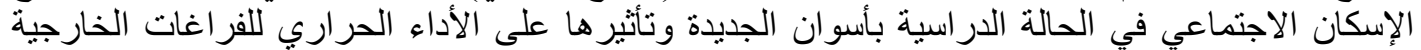

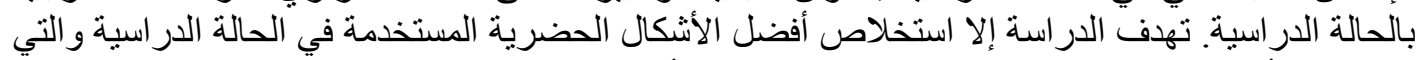

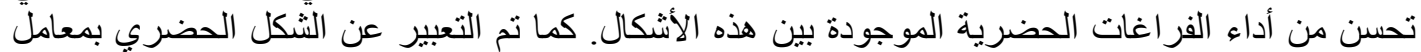

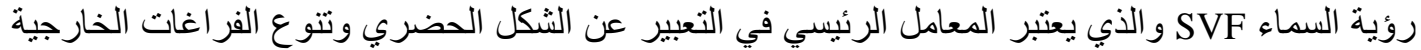

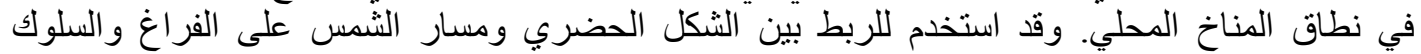
الحراري للفر اغات الخارجية.

للوصول لهدف الدر اسة تم عمل قياسات مناخية بالموقع و عمل محاكاة للأداء المناخي باستخدام برنامج ENVI-met

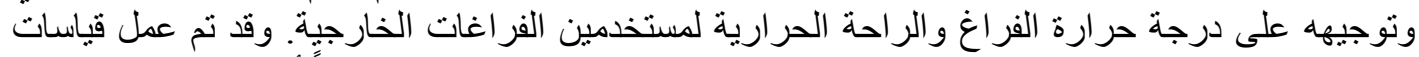

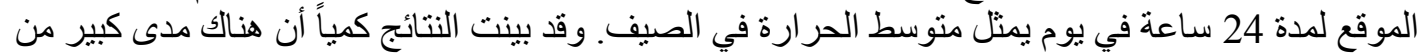

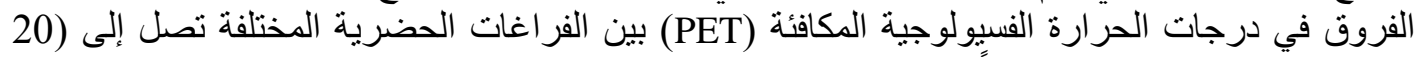

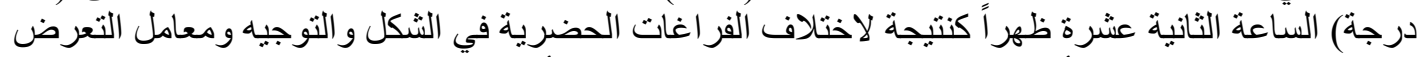

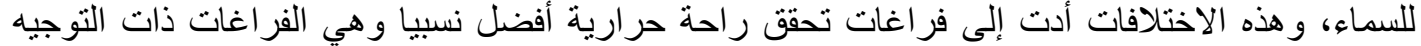

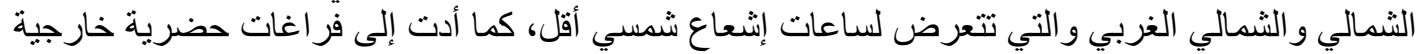

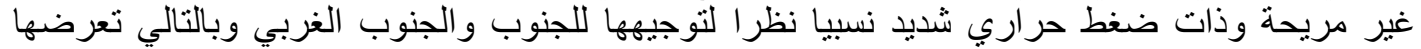

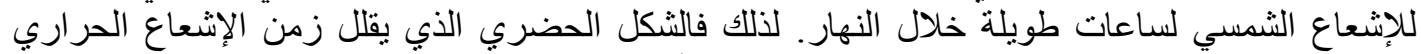

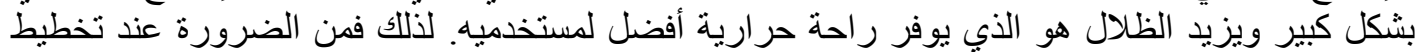

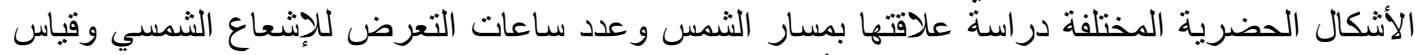

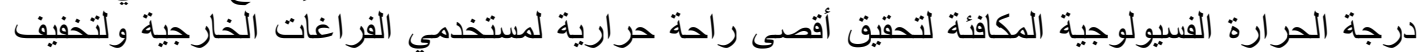

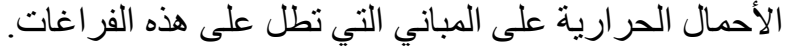

